Кузнецова Татьяна Анатольевна, к.Х.Н., доцент, Ангарский государственный технический университет, e-mail: kuztatang@yandex.ru

Фереферов Михаил Юрьевич, к.т.н., доцент, Ангарский государственный технический университет, e-mail: fmu@agta.ru

Павшинская Анастасия Вячеславовна, обучающийся, Ангарский государственный технический университет, e-mail: pavshinskiy1970@mail.ru.

ОЧИСТКА БЕНЗИНОВ ТЕРМОКАТАЛИТИЧЕСКИХ ПРОЦЕССОВ НЕФТЕПЕРЕРАБОТКИ РАСТВОРАМИ ЭТАНОЛАМИНОВ

Kuznetsova T.A., Fereferov M.U., Pavshiskaya A.V.

\title{
CLEANING GASOLINE THERMOCATALYTIC REFINING PROCESS SOLUTIONS OF ETHANOLAMINES
}

\begin{abstract}
Аннотация. Рассмотрены процессы очистки различных нефтепродуктов растворами моноэтаноламина, представлены результаты экспериментов по очистке бензинов каталитического крекинга и бензиновой фракции гидроочистки дизельного топлива растворами моноэтаноламина.
\end{abstract}

Ключевые слова: очистка, бензин, моноэтаноламин.

Summary. The report considers the processes of purification of various petroleum products with solutions of monoethanolamine and presents the results of experiments on purification of catalytic cracking gasoline and gasoline fraction of diesel fuel hydrotreatment with solutions of monoethanolamine.

Keywords: purification, gasoline, monoethanolamine.

На нефтеперерабатывающих заводах очистку жидких нефтепродуктов, и в первую очередь бензиновых фракций различного происхождения, от сернистых соединений производят путем их обработки растворами щелочи. Чаще всего используют растворы едкого натра. Этот процесс называется защелачиванием. Защелачиванию подвергаются бензиновые фракции каталитического крекинга, коксования и гидроочистки дизельного топлива. Щелочь взаимодействует с некоторыми сернистыми соединениями, например:

$$
\begin{aligned}
\mathrm{H}_{2} \mathrm{~S}+2 \mathrm{NaOH} & =\mathrm{Na}_{2} \mathrm{~S}+2 \mathrm{H}_{2} \mathrm{O} \\
\mathrm{RSH}+\mathrm{NaOH} & =\mathrm{RSNa}+\mathrm{H}_{2} \mathrm{O}
\end{aligned}
$$

Процесс защелачивания достаточно эффеективен в первую очередь по отношению к сероводороду и меркаптанам. Сульфиды и дисульфиды, образованные углеводородами, со щелочами практически не реагируют. Следует также отметить, что при защелачивании меркаптаны могут подвергаться в известной степени окислению кислородом воздуха с образованием дисульфидов по реакции:

$$
2 \mathrm{RSH}+\mathrm{O}_{2}=\mathrm{RS}-\mathrm{SR}+2 \mathrm{H}_{2} \mathrm{O}
$$


Применение защелачивания приводит к образованию значительного количества серощелочных сточных вод, поэтому для их очистки требуется применение специальных очистительных установок [1].

В мировой практике и в нашей стране ведутся работы по внедрению других методов очистки нефтепродуктов от сернистых соединений. Так, например, разработан процесс с применением четвертичных аммониевых оснований, в виде водно-метанольного раствора одного из таких оснований, известный под названием реагент SX-2081. При этом сероводород и меркаптаны переводятся в нейтральные сульфиды. Другим примером демеркаптанизации нефти и нефтепродуктов является применение специальных катализаторов прямого окисления низших меркаптанов кислородом воздуха в дисульфиды - технология ДМС. Для очистки нефтяных фракций и нефти от сероводорода также применяется обработка их смесью водных растворов фрормальдегида и моноэтаноламина (МЭА) [2].

На НПП АО «АНХК» на установке гидроочистки дизельного топлива для очистки отгона (бензиновой фракции) вместо щелочи применяется раствор МЭА. Эффрективность очистки отгона от сероводорода достаточно высокая. Кроме этого отработанный раствор МЭА легко регенерируется с выделением сероводорода в десорбере, служащим для регенерации раствора МЭА после очистки водородсодержащего газа. Представляет промышленный интерес применение этаноламинов для очистки бензинов от сернистых соединений и на других установках НПП, в частности, на установке ГК-З.

С этой целью были проведены эксперименты по очистке широкой фракции бензина каталитического крекинга растворами МЭА. В качестве исходного сырья был отобран бензин после колонны стабилизации блока каталитического крекинга перед защелачиванием. По данным анализа, представленным предприятием, содержание общей серы составляло 0,0057 \% масс., меркаптановая сера составляла 0,0210 \% масс., сероводород составлял 0,0118 \% масс. После обработки исходного бензина водными растворами МЭА содержание сероводорода снизилось до 0,0002 \% масс., содержание меркаптановой серы снизилось до 0,0047 \% масс. Полученные результаты свидетельствуют о возможности замены щелочной очистки очисткой на основе раствора МЭА.

\section{ЛИТЕРАТУРА}

1. Капустин В.М., Гуреев А.А. Технология переработки нефти. В 4-х частях. Часть вторая. Физико-химические процессы. - М.: Химия, 2015. $400 \mathrm{c}$.

2. Мазгаров А.М., Набиев А.И. Технология очистки сырой нефти и газоконденсатов от сероводорода и меркаптанов. - Казань: Казан. Ун-т, 2015. -38 c. 